\title{
THE RE-PRODUCTION OF THE HISTORICAL CENTER OF İSTANBUL IN 2000s: A CRITICAL ACCOUNT ON TWO PROJECTS IN FENER - BALAT (1)
}

\section{Evren AYSEV DENEÇ*}

Received: 28.01.2014; Final Text: 11.11.2014

Keywords: Urban space production; Neoliberal urban politics; İstanbul; Golden Horn.

1. In addition to the findings of the PhD. thesis titled as "The Role of the Architect in the Production of Urban Space: İstanbul Example"; prepared at İstanbul Technical University, conducted by Associate Prof. Dr. İpek Akpınar and Prof. Dr. Arda İnceoğlu; this research consists of new and expanded data. The scope of the research is largely broadened and elaborated within a new perspective.
Contemporary city is a multiplicity having social, political, cultural and economic projections. Production of urban space involves various mechanisms in which different interest groups play different roles in accordance with their identity, responsibility and agenda. In that sense, contemporary city is a ground of collision of conflicting interests that produce and transform urban space. Controlling urban space is a power struggle among different actors with varying agenda; constituting the basis of physical and socio-economic urban conversion (Keil, 2002). In the process of urban contradiction and change; social classes, capital accumulation and urban governments are three basic components with a fundamental role (Şengül, 2009).

İstanbul has currently become the 'stage' of extensive urban space production and re-production processes; almost becoming a construction site in itself. The urban boundaries extend on a daily basis, while numerous transformation projects within the city center raise crucial questions. The cityscape is subjected to critical interventions that aim to re-shape some of the major cultural, historical and natural landmarks of the city. In short, İstanbul is currently undergoing a series of mega scale operations that will change the fabric of the city irreversibly.

The mainstream space production processes in the İstanbul of 2000s are shaped by the neoliberal urban policies adopted by large scale capital, central and local governments that work hand in hand. In order to comprehend these processes, it is crucial to develop an understanding of the current urban political climate. This paper aims to take a critical look into the urban space production mechanisms of İstanbul's historical residential center through an in depth comparative analysis of two consecutive projects that have taken place at the Golden Horn during the 2000s; having acutely different social, spatial and economical approaches and agendas; namely the Fener Balat Rehabilitation Project (FBRP) initiated by the European Union (EU) and The Fener, Balat, Ayvansaray 
Urban Renewal Project (FBAURP) initiated by Fatih Municipality (FM). Within the scope of paper; firstly an overview of the urban political dynamics of İstanbul is presented. Secondly, a brief discussion on the geographical context of the projects is introduced. Then, a discussion on the urban space production mechanisms of 2000s İstanbul is delivered through the investigation of two projects stated above. Finally, concluding remarks are presented.

\section{POLITICAL SETTING}

Neoliberal politics have been increasingly dominating the global economy within the last 30 years. The theory of neoliberalism as defined by Harvey $(2005,2006)$, suggests that individual liberty and freedom can best be protected by free markets, strong private property rights and free trade where state should keep its distance from the economy and act merely as a regulator that preserves the institutions of the market. The term "neoliberalism" is mainly used to express the market oriented approaches after 1980s and to interpret the basic aspects of urban structuring in the 2000s (Brenner and Theodore, 2004). However, the economic implications of neoliberal politics have increasingly gained a pejorative meaning aligned with the abolishment of social welfare and civil rights in favor of global capitalism and consumerism (Bourdieu, 1999, 2003; Chomsky, 1999; Touraine, 2001). In the critical literature, neoliberalism mainly indicates the ultimate domination of market economy despite its social, democratic, environmental and urban shortcomings; diminishing of the social and civil rights in favor of capitalism and intense privatization that exhausts natural, cultural and urban assets belonging to public.

Starting from the 1980s, the discussion above becomes increasingly relevant for Turkey, especially for İstanbul (Keyder, 2000). The struggle over the reproduction of space and the rent distribution in İstanbul is frequently addressed in current urban literature (Yalçıntan, 2005; Gülöksüz, 2002; Yirtic1, 2005). Between the years 1980 and 2000, neoliberal urban politics that aim Turkey's gradual integration to global markets are implemented parallel to populist urban policies that make concessions for the legalization of informal urban settlements (Öktem, 2011). With the 2000s however, a fundamental shift occurs in the urban governance policies of Turkey (Kuyucu, 2009). In 2002, JDP (Adalet ve Kalkınma Partisi) became the ruling party of the central government in Turkey, in addition to ruling a majority of the local governments, including İstanbul. Thus, the urban governing structure of İstanbul, dominated by JDP, was in the same camp for the first time since 1980's; providing vast and unopposed grounds for implementation of their urban policies. From this date on, tolerance for informal mechanisms; being the primary urban space production practices until then; disappear as the neoliberal urban politics aiming the capitalization and commodification of urban space becomes institutionalized. This could be interpreted as the end of urbanization of the labor force and the beginning of urbanization under the hegemony of capital (Şengül, 2009; Şen, 2014). In this context, large scale property led urban renewal and transformation projects issued by local governments, mix used 'mega projects', shopping malls and high-rise office blocks initiated by global capital and extensive mass housing production executed by Mass Housing Department (TOKI) become the new urban forms of neoliberal urbanism in İstanbul (Öktem, 2005; Kurtuluş, 2005; Kuyucu and Ünsal, 2010). In fact, economy of Turkey in the 2000s is fundamentally 
2. For additional information see: Ataöv and Osmay, 2007.

3. Sulukule and Tarlabaşı Urban

Transformation projects are two of the

contraversial processes that have currently

been executed in İstanbul. leaning on the construction sector. Basic strategies for satisfying the insatiable land requirements of this sector are; opening natural assets such as forests, coasts and water supplies to construction, privatization of public land, confiscating private land via urgent expropriation and changing planning regulations of existing lots in order to raise rent value (Çavuşoğlu, 2011). The result of this extensive construction activity is the expansion of the limits of the city on a daily basis, while the building stock at the center is demolished to be re-produced so as to increase rent value.

One of the major agents enabling the transformation of urban space into capital accumulation areas are the local governments that gained autonomy and power with a series of legal regulations after 1984 (2). Legal regulations made especially within the 2000s transfer the right to redefine, regulate and redistribute urban property to local governments; enabling them to have the power to reshape urban structure via large scale urban renewal projects (Günay, 2013). In this respect, Marmara earthquake, underlining the lack of quality of İstanbul's building stock, have become a tool for political legitimization for the urban renewal schemes, creating a "discourse of urgency" as pointed out by Bartu Candan and Kolluoğlu (2008). This discourse, articulated around natural and "naturalized" disasters such as crime, migration, overpopulation, traffic congestion is deliberately utilized to justify massive urban transformation projects around the city (Altıntaş, 2012).

The urban space policies discussed above mainly operate as the commodification of urban space through urban transformation and redistribution of rent value. Urban transformation has become a tool for a profit based new urban economy, reflecting the speculative pressure exerted by private capital. Despite broad based public opposition, urban governments tend to exclude the citizens from decision making processes in favor of the demands of large scale capital; producing a fundamental problem in terms of urban democracy (Şen, 2014). Although the notion of urban transformation is supposed to be advantageous for all social classes; the current implementations in İstanbul fail to prove their legitimacy, becoming profit oriented executions based on the re-structuring of space rather than solving physical and socio-economic problems of the transformation area (3). This approach conceptualizes urban space as an economical asset rather than milieu that generates urbanity; therefore disregards the social dimension of the urban condition that demands transformation. Hence it only transfers the actual problem to another - less favorable - section of the city, instead of addressing the problem (Şen, 2006; Kuyucu, 2011; Kurtuluş, 2006). The urban agenda aiming the total inclusion of urban land to capitalist economy is bound to have acute impacts on physical, social and demographical levels, paving way for social and spatial segregation, emergence of spaces of decay, distressed and privileged spaces (Bartu Candan and Kolluoğlu, 2008, Öktem, 2011). In this respect, the neoliberal city is becoming a new target for civil opposition and public contest (Ekmekçi, 2012; Özdemir, 2013).

In the process of physical, social and cultural privatization and commodification of urban space; the areas with the highest profit margin seem to be the historical centers, deterioration zones at the city centers and slum areas. The profitability due to their central location, the historical, cultural, spatial qualities they possess, as well as the economical fragility and legal defenselessness of the existing residents make these areas primary targets for urban transformation projects. The motive lying 
beneath numerous transformation and renewal projects is the creation of a tourism economy based on the advantages mentioned above; leading to a "cultural based urban economy" as referred by Zukin (1998, 825-39). Associated with physical interventions and destruction; these projects aim the radical transformation of the urban space via demolishing the old for reconstruction (Tekeli, 2011). In that sense, large scale, property based renewal projects are becoming instruments of "urbicide" in İstanbul, leading to a model of urban destruction, as pointed out by Günay (2013).

To sum up, the urban space production of İstanbul is going through a critical stage in the 2000s. Urban governments, as powerful actors dominating the construction and real estate markets of the city attempt to change the property regime by privatizing valuable public land, issuing new development rights, interfering with slum areas and residential neighborhoods within the historical center under the name of urban transformation. The result of these endeavors is the gradual transfer of the property and usage rights of urban land from citizens to the dominating actors of the real estate market. This situation has crucial impacts on the spatial production dynamics of the city. The consortium of central, local governments and large scale capital make it challenging to create grounds of resistance and negotiation with regards to large scale projects that affect lives of citizens. In this context, the city is no longer a free space where the "right to the city"; as underlined by Lefebvre and Harvey; could be exercised, as the public welfare is suppressed by the profit oriented agenda imposed upon the city (Lefebvre, 1996; Harvey, 2008). The deprivation of urban rights and public participation demand a radical reconstruction of social, political and economic relations within and beyond the city, as pointed out by Purcell (2002).

\section{GEOGRAPHICAL SETTING / THE GOLDEN HORN}

With regards to the discussion above, The Golden Horn has been a battleground of different urban intervention tactics since 1980s. As the northern natural bay of İstanbul, the Golden Horn has been a significant site as a harbor, a naval base, an important residential area as well as an appropriate location for various types of industry throughout the history. Having a multi-cultural ethnic identity, the Golden Horn became one of the first public recreation areas of the Ottoman Empire around the eighteenth century. The area not only hosted some of the prominent minority neighborhoods, but also became an important religious center of the city with institutions and sacred centers such as Fener Greek Patriarchate and Eyüp. Located at the south of the Golden Horn, Fener and Balat neighborhoods are important historical residential areas of İstanbul, populated mostly by the Greek, Jewish and Armenian minorities until the mid-20th century.

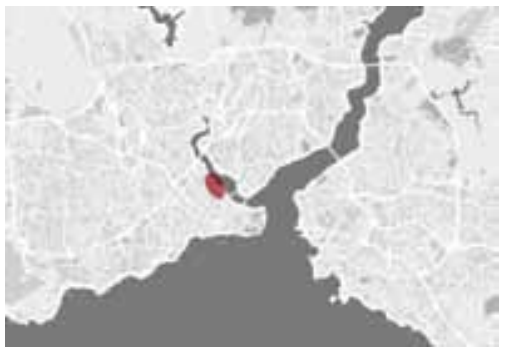

Figure 1. Map of the Historical Peninsula and the Golden Horn; İstanbul.
The cosmopolitan demography of the area begun to dissolve within the first half of the twentieth century. Many residents belonging to ethnic minorities have left the area as Muslim immigrants from Anatolia took their place. Around late 1940s, an accumulation of developing industries begun to populate the area; attracting large numbers of immigrant workers. This intense industrial settlement however, gave way to heavy environmental pollution and urban deterioration.

During the 1980's, the revitalization of the Golden Horn became a top priority of Bedrettin Dalan, the mayor of the time (1984-1989). With a top down initiative, the local government intended to regenerate the area as 
a cultural and touristic center. Through these operations, a number of historical neighborhoods were demolished, the industrial plants were removed to a great extent, roads and green areas were built and the water of the Golden Horn was cleaned. In short, The Golden Horn has gone through drastic changes during this period; including massive destructions of the coastal urban texture. Since Dalan, the local governments; mainly from the right wing; have followed his footsteps in terms of top down initiation, rehabilitation by demolition and the agenda of marketing İstanbul in a global scale (Bezmez, 2009).

In the last decades, the Golden Horn has been subjected to a number of urban transformation projects with different approaches and initiating actors. Some of the projects are executed solely by the local administration while in other projects, a private investor or a non-profit organization carries the initiative. The process and the end product acutely vary in terms of the identity, position and agenda of the initiating actor (Aysev and Akpinar, 2009). Activities of the local administrations aiming to revitalize the area as a recreational center create crucial discussions in the architectural and urban domain.

\section{PROJECTS}

Among the most debated urban transformation areas in İstanbul, Fener - Balat - Ayvansaray coastline located at the Golden Horn is currently undergoing a controversial process. Within 2000s, the area was subjected to two consecutive urban renewal attempts, namely Fener Balat Rehabilitation Program (FBRP) sponsored by EU and Fener, Balat, Ayvansaray Urban Renewal Project (FBAURP) commissioned by FM. The controversies between the projects begin with the initiating agenda. While the first project prioritized the improvement of socio-economic conditions as well as physical restoration, the latter aimed to transform the area into a cultural and touristic center, giving way to gentrification and urban displacement (Şişmanyazıcı and Turgut Yıldız, 2010). Within the political setting discussed above, FBRP could be considered as a deviation from the dominating neoliberal urban implementations with its non-profit agenda while FBAURP demonstrates an example of mainstream market oriented urban interventions discussed above. These cases are selected within the scope of the study as they present two opposing urban intervention approaches within the same geographical and social context around a similar time interval, therefore offering an opportunity for a comparative analysis.

Below, two projects are discussed through a threefold analysis focusing on the project formulation stage, implementation stage and impact assessment. The comparative analysis structure is set in order to reveal the similarities, differences, successes and shortcomings of the projects in every stage; enabling a ground for the discussion of an alternative urban implementation strategy. In the project formulation stage, the projects will be analyzed in terms of initiation processes, financial models, involved actors, legislative basis, scope and agenda. In the implementation stage, the projects will be analyzed in terms of spatial / physical implementations and social / economic implementations. Finally, in the impact assessment stage, the projects will be analyzed in terms of physical impacts, social impacts and public reactions. The research sources consist of project documents such as architectural drawings, photographs, project reports and interviews with the executive officials of the projects (local co-director of FBRP and 


\begin{tabular}{|l|l|l|}
\hline PROJECT FORMULATION & PROJECT IMPLEMENTATION & $\begin{array}{l}\text { IMPACTS OF THE } \\
\text { PROJECTS }\end{array}$ \\
\hline $\begin{array}{lll}\text { Initiation, Financial Model } \\
\text { and Involved Actors }\end{array}$ & Spatial / Physical Implementations & Physical Impacts \\
\cline { 1 - 1 } Legislative Basis & Social / Economic Implementations & Social Impacts \\
\cline { 1 - 1 } & & Public Reaction \\
\hline
\end{tabular}

Projects Director of FBAURP, general secretary of FEBAYDER) as well as referencing prior academic studies.

\section{Project Formulation}

The differences between two projects begin with the formulation stage. The identity and objectives of the initiating actors are key factors that define the nature of the urban intervention. The organizational structure, division of labor and financial model are all shaped by the initiating motivation. The scope and agenda of the projects are produced in line with that initial definition. The legislative basis of the projects is also critical as the scope and agenda are either based on or legitimized accordingly. In short, the project formulation stage defines the way in which the implementation processes take place; paving way for the accomplishments or the shortcomings of the projects.

Initiation, Financial Model and Involved Actors

FBRP is one of the few examples of a non-profit initiation aiming to improve the life standards of a deteriorating historical residential area in Istanbul. In fact, the multi-actored and participative project structure that concentrates on rehabilitating the area not only physically but also economically and socially makes it an unprecedented experience for Turkey. The ideation of FBRP goes back to the 1996 Habitat II Conference on Human Settlements, held in İstanbul. As a pilot project, FBRP was initiated by a protocol between Fatih Municipality (FM) and European Commission in 1997 (ICOMOS/UNESCO, 2006). Sadettin Tantan, the mayor of Fatih at the time, was a key initiating figure of the project (Altınsay, 2010; Bezmez 2009). With the participation of European Union (EU), French Anatolian Research Institute, UNESCO and Fener Balat Association, this protocol was followed up by a feasibility study where the project was modelled in detail, producing a report on the rehabilitation of Fener and Balat districts (Fatih Municipality et al., 1998).

According to the 1998 report, financing of the project was to be provided collectively by Mass Housing Department of Turkey (TOKI) and EU (Fatih Municipality et al., 1998). However, this model had changed in the implementation phase and TOKİ did not provide any financial support. As a result, EU became the sole financer of the project while FM was defined as the beneficiary partner. In 2000, a financial protocol of 7 million Euros was signed between EU, FM and The Turkish Ministry of Treasury.

The initiating actors of the project, being FM and the EU formed a partnership of local government and non-profit organization. Under this partnership, a multi-actored organization structure was formulated, emphasizing public participation and transparency. A multi-national Consortium won the service tender organized by the EU and chosen as the project executer. A Technical Support Team (TST), in charge of the preparation of project documents and on sight implementation control was appointed by the Consortium. Professional contractor firms carried out 
the restoration work under the supervision of TST. Alongside TST, four specialists; being the National Director, the Local Co-Director, Coordinator for Works and Supply and the Financial Director were assigned to conduct the FBRP. A participation forum was formulated with the intention of obtaining public feedback. Finally, an advisory committee was constituted as a mechanism of supervision (Altınsay, 2010).

Both positive and negative aspects of having such a multi-actored project structure were experienced during the execution process. First of all, the attitude of FM, as the initiator and beneficiary partner of the project, drastically changed due to the shift in its administrative and political agenda. In the beginning, the Municipality played an effective role of coordination including the preparation of the feasibility study, signing of the financial agreement with EU, providing public participation, managing tenant relations, supporting the TST, controlling the project documents and implementation (Eken, 2010). However, the governance of the Municipality changed prior to the execution phase. The new local government from Justice and Development Party (JDP) had an entirely different political agenda that perceived urban space as a financial source, thus aimed to capitalize it entirely. At this point, the non-profit agenda of the FBR Program and neoliberal policies of the new local government inevitably contradicted, resulting in the loss of political support behind the project (Aysev, 2012). The ICOMOS/UNESCO Screening Report outlines the problems caused by the inadequate contribution of the FM as; lack of municipality participation in terms of maintaining sustainability; inadequacy of the "Department of Preservation of the Historical Environment" connected to FM; lack of a coherent "World Heritage Site Governmental Plan" and lack of producing mechanisms to collect data and know how produced during the project in order to generate a model for the coming projects" (ICOMOS/UNESCO, 2006). The report defined these insufficiencies as a substantial threat towards the success and sustainability of the project; concluding that "FM did not adopt the project as its own, did not coordinate its activities in line with the project and did not assign adequate staff" (ICOMOS/UNESCO, 2006).

Secondly, the inhabitants played a crucial role in the project, taking an active part in the design and implementation phases (Eken, 2010). Although one-to-one relationship TST established with the residents was positive in terms of community participation, it created practical difficulties in implementation. The local co-director of the project underlines the challenges of having to deal with 121 clients with different demands and needs; describing it as a "fulfilling yet extremely difficult experience" (Altinsay, 2010). The unusual and on-site executive involvement of the architect; with the job description as TST; playing not only a technical but also a social and moderating role is a unique experience that redefines end enlarges the disciplinary boundaries of architecture (Aysev, 2012). Nevertheless, the fact that public relations were not managed by dedicated professionals was disadvantageous for the procession and public communication of the project.

Thirdly, even though the complicated organizational structure was positive for supervision and transparency of the process; the hefty bureaucracy, especially with regards to the EU, became another factor that slowed down the execution (Altınsay, 2010). 
Table 2. Actors of FBRP.

4. The contract covering the urban renewal of Fener, Balat Ayvansaray coast line and fifty nine building blocks up to the historical city walls was commissioned in 30.04 .2007 . This date has raised a lot of question marks in terms of legitimacy; as the initiation of project tender was held in 18.07.2007; four months after the contract, as stated by the general secretary of FEBAYDER, İbrahim Güntekin (FEBAYDER, 2009).

\begin{tabular}{|l|l|}
\hline \multicolumn{2}{|l|}{ ACTORS OF THE FENER BALAT REHABILITATION PROJECT: } \\
\hline INITIATOR & $\begin{array}{l}\text { European Union (Financer) and Fatih Municipality } \\
\text { (Beneficiary) }\end{array}$ \\
\hline FEASIBILITY STUDY & $\begin{array}{l}\text { European Union, Fatih Municipality, French - Anatolian } \\
\text { Research Institute, UNESCO and Fener Balat Association }\end{array}$ \\
\hline CONSORTIUM & $\begin{array}{l}\text { Foment Ciutat Vella SA (Spain), IMC (England), GRET } \\
\text { (France), Foundation for the Support of Women's Work }\end{array}$ \\
\hline IMPLEMENTATION & $\begin{array}{l}\text { Fener Balat Rehabilitation Program / Technical Support } \\
\text { Team (TST) / Contractor Firms }\end{array}$ \\
\hline INTERFACE & Participation Forum \\
\hline ADVISORY COMMITTEE & $\begin{array}{l}\text { Relevant Ministries, European Commission, Fatih } \\
\text { Municipality, Cultural Heritage Conservation Board, } \\
\text { Neighborhood Representatives, Technical Support Team }\end{array}$ \\
\hline USER & Existing residents \\
\hline
\end{tabular}

Unlike FBRP, FBAURP can be conceptualized as an outcome of the neoliberal policies of İstanbul's urban governments. Consecutive to FBRP, FM with a changed governing structure teamed up with a private enterprise namely GAP Construction in order to produce FBAURP (4). The private capital with a profit based agenda played a key role in the formulation and implementation of FBAURP. GAP Construction single handedly conducted the tasks of coordination, project management, construction, financing and real estate development. The company assigned and employed the architectural and consultant groups, determined the scope and agenda of the project and provided 200 Million USD for the execution phase.

FM as the local government and project partner acted as a legitimizing agent that negotiated public rights to a private enterprise (Aysev, 2012). It is hard to say that FM fulfilled the civic duty of defending public welfare, representing the rights of the inhabitants, communicating the process with public and establishing transparency as a mediating agent. The central government that prepared the legal structure for the project could also be conceptualized as a key actor in the process.

The inhabitants played a unique role of civil resistance; in terms of protesting and struggling against the violation of their property rights (FEBAYDER, 2009). The role of the urban governments and the inhabitants will be discussed further in course of the study.

\begin{tabular}{|l|l|}
\hline \multicolumn{2}{|l|}{ ACTORS OF THE FENER BALAT AYVANSARAY URBAN RENEWAL PROJECT } \\
\hline INITIATING ACTOR & Fatih Municipality, Central Government \\
\hline CONTRACTOR & GAP Construction \\
\hline ARCHITECTURAL FIRMS & $\begin{array}{l}\text { Trafo Architects, Net Architects, Çinici Architects, Hazan } \\
\text { Architects, Sepin Architects, Teğet Architects, HF } \\
\text { Architects, Ütopya Architects }\end{array}$ \\
\hline CONSULTANTS & $\begin{array}{l}\text { Yrd.Doç.Dr. Zeynep Kuban, Dr. Sinan Genim, Prof.Dr. } \\
\text { Güzin Konuk, Prof.Dr. Sercan Özgencil Yıldırım, Prof.Dr. } \\
\text { Murat Güvenç, Prof.Dr. Hülya Turgut, Arife Deniz Oktaç. }\end{array}$ \\
\hline RESISTANCE & Inhabitants, FEBAYDER \\
\hline USER & Mid-high level income group \\
\hline
\end{tabular}




\section{Legislative Basis}

With the 1980s, the legal framework of conservation in Turkey evolved to a structure where the agencies responsible of preserving cultural heritage were clearly defined. The Ministry of Culture became the principal agency of conservation (Şahin Güçhan and Kurul, 2009). According to this structure, all interventions towards cultural heritage should comply with the ministry regulations and be approved by the Regional Conservation Councils; while municipalities became responsible for procuring and implementation of conservation master plans. FBRP is legally based on the Law 2863 (Law of Conservation of Cultural and Natural Entities), issued in 1983 within this context. This law enabled a transparent and collaborative project structure open to supervision (Eken, 2010). FM was in charge of supervising the project documents prepared by the TST. The documents were then approved by the Protection Board of Natural and Cultural Assets, before implementation. Furthermore, EU as an international partner inspected the advancement of the project on a regular basis (Altnsay, 2010). In short, FBRP is legally based on the Law 2863 that enables a meticulous regulation and control of the urban interventions towards historical cultural heritage.

Coming to the mid 2000s, the legal structure of historical conservation was subjected to a shift (5). A series of legal regulations took place within the last decade that turned İstanbul into an implementation area of large scale urban transformation projects. With the issuing of The Protection by Renewal and Utilization by Maintenance of Deteriorated Historical and Cultural Assets Law (No. 5366); FM became one of the active local governments in terms of producing urban transformation projects including FBAURP.

The Law 5366 gave way to controversial urban transformation implementations, receiving intense criticism. One of the main points of criticism was that the law disregarded the social, economic and cultural context of urban transformation areas; reducing the process to a mere physical intervention. Moreover, the law included articles that immunized urban transformation implementations from all legal sanctions; instead of improving existing legal structure (TMMOB, 2006). Demands of the right holders or providing public participation were not taken into account. On the contrary, the law invalidated the large scale planning decisions and granted the right of making new development decisions solely to municipalities, by preparation of development plans for urban transformation. Any opposition that might come from right owners to these decisions could be confronted with rulings of "urgent expropriation" (TMMOB, 2006). To sum up, the law:

- Takes the areas of transformation merely physically; ignores the cultural, social and economic dimensions.

- Ignores the rights of the inhabitants to be a part of the decision making mechanisms.

- Takes the city in fragments with regional planning decisions, instead of preparing an integrated intervention strategy.

- Transfers the negotiation of dwelling and property rights of the citizens to private sector, therefore leaving the transformation areas in the hands of the dynamics of the real estate market. 
In short, FBAURP is based on the Law 5366 having controversial aspects that could lead to profit based fragmental transformation processes that ignore public welfare, deepen urban segregation and social inequality.

Scope and Agenda

The objectives of FBRP are based on providing housing for every individual, creating livable human settlements, enhancing participatory planning and gender equality; as stated in the Habitat II Report (1996). The main reasons for the selection of Fener and Balat neighborhoods as a pilot location were the unique urban fabric and historical heritage of the neighborhoods that could be restored with a relatively small budget; the central location of the neighborhoods; the unfavorable environmental and living conditions of the inhabitants (FM, 1998).

In this context, the program aimed for social rehabilitation as much as building restoration; encouraging active public participation in decision making and implementation processes. Major goals of the program were stated as;

- socio-economic rejuvenation of the neighborhoods via sustainable urban rehabilitation,

- development of income generating activities for the inhabitants,

- improving the technical capacity of FM in terms of protecting cultural heritage,

- stimulation of further restoration of other buildings in the neighborhoods,

- creation of an urban rehabilitation model that could be applied in other neighborhoods (FBR Program, 2005).

In this respect, the agenda of the project is to trigger a sustainable rehabilitation process that could socially, economically and physically improve the area. Nevertheless, due to the budget and time limitations, the scope of the project had to be narrowed down during the implementation stage. The reduced version of the project scope involved four main issues namely;

- a limited (symbolic) amount of restoration work,

- social rehabilitation of the area by producing programs mainly towards women and children,

- the rejuvenation of historical Balat market as an economical rehabilitation move,

- producing a solid waste management program (FBR Program, 2005).

Despite the modest budget and limited scope of FBRP; FBAURP is one of the large scale urban transformation projects of Turkey, with a project area of 280.000 M2 (GAP Construction, 2007). The project scope is the urban renewal of 909 lots with 370 registered buildings in 59 blocks, as well as the redesign of Ayvansaray coastline. The project coordinator summarizes the project criteria as; taking the preservation master plan as a fundamental basis; the reconstruction / removal of poorly constructed building stock upon the historical city walls; amalgamation of the small lots in order to provide "comfortable living standards" (Kivircik, 2010).

Nevertheless, the project agenda has fundamental deficiencies in physical, social and legal terms. First of all, the project intends the total and 
Table 4. Project Formulation stages of FBRP and FBAURP.

\begin{tabular}{|c|c|c|}
\hline & FBRP & FBAURP \\
\hline Initiation & $\begin{array}{l}\text { Local Government (FM), Non- } \\
\text { Profit Organization (EU) }\end{array}$ & $\begin{array}{l}\text { Local Government (FM), } \\
\text { Central Government, Private } \\
\text { Sector }\end{array}$ \\
\hline Financial Model & Non-Profit Organization (EU) & $\begin{array}{l}\text { Private Sector (GAP } \\
\text { Construction) }\end{array}$ \\
\hline Involved Actors & See Table 2 & See Table 3 \\
\hline Legislative Basis & Law No: 2863 & Law No: 5366 \\
\hline Scope & $\begin{array}{l}\text { A limited scope involving } \\
\text { restoration, social rehabilitation, } \\
\text { economic rehabilitation and } \\
\text { solid waste management }\end{array}$ & $\begin{array}{l}\text { Urban renewal of } 909 \text { lots with } \\
370 \text { registered buildings in } \\
59 \text { blocks, redesigning of the } \\
\text { Ayvansaray coastline }\end{array}$ \\
\hline Agenda & $\begin{array}{l}\text { Triggering a sustainable } \\
\text { rehabilitation process that } \\
\text { socially, economically and } \\
\text { physically improves the area }\end{array}$ & $\begin{array}{l}\text { Profit generation by physical } \\
\text { transformation, gentrification } \\
\text { and displacement }\end{array}$ \\
\hline
\end{tabular}

irreversible physical transformation of the area; disregarding the continuity of social, demographic and historical urban texture. As the existing urban pattern of small lots does not meet the spatial needs for large scale investments, the project tends to destroy this pattern and introduce a new one through amalgamation and removal (Dinler, 2013). The architectural decisions regarding this physical transformation will be discussed in the following chapter.

Secondly, the project violates the basic property rights of the inhabitants. This violation; widely protested by the residents, indicates an agenda of gentrification and displacement of the current demography, in favor of a new, wealthier resident profile of middle - high income (FEBAYDER, 2009).

Thirdly, the project has no social scope or agenda, being merely a physical intervention that aims to raise the rent value of the area. The project coordinator admits to the fact that Law 5366, forming the legal basis of the project, lacks a viable social agenda and the urban governments have to take an active role of developing social policies in transformation projects (Kıvircik, 2010).

\section{Project Implementation}

The implementation stages of the two projects have a number of differences. The major difference is that FBRP is completed; therefore it is possible to analyze and evaluate the project through the work that has been done. On the other hand, the physical implementation of FBAURP has not been commenced due to a number of law suits. Therefore, it could only be assessed through the analysis of the project.

Physical Implementations

The physical implementation of FBRP commenced in 2003. The job description of TST involved the

- selection of buildings to be restored according to physical and social assessment criteria,

- preparation of the restoration projects, obtaining the approval of the Board of Preservation and collecting the construction permits for the buildings to be restored, 
Figure 2. Project Site of FBRP (FBR Program, 2005).

Table 5. Fener Balat Rehabilitation Project.

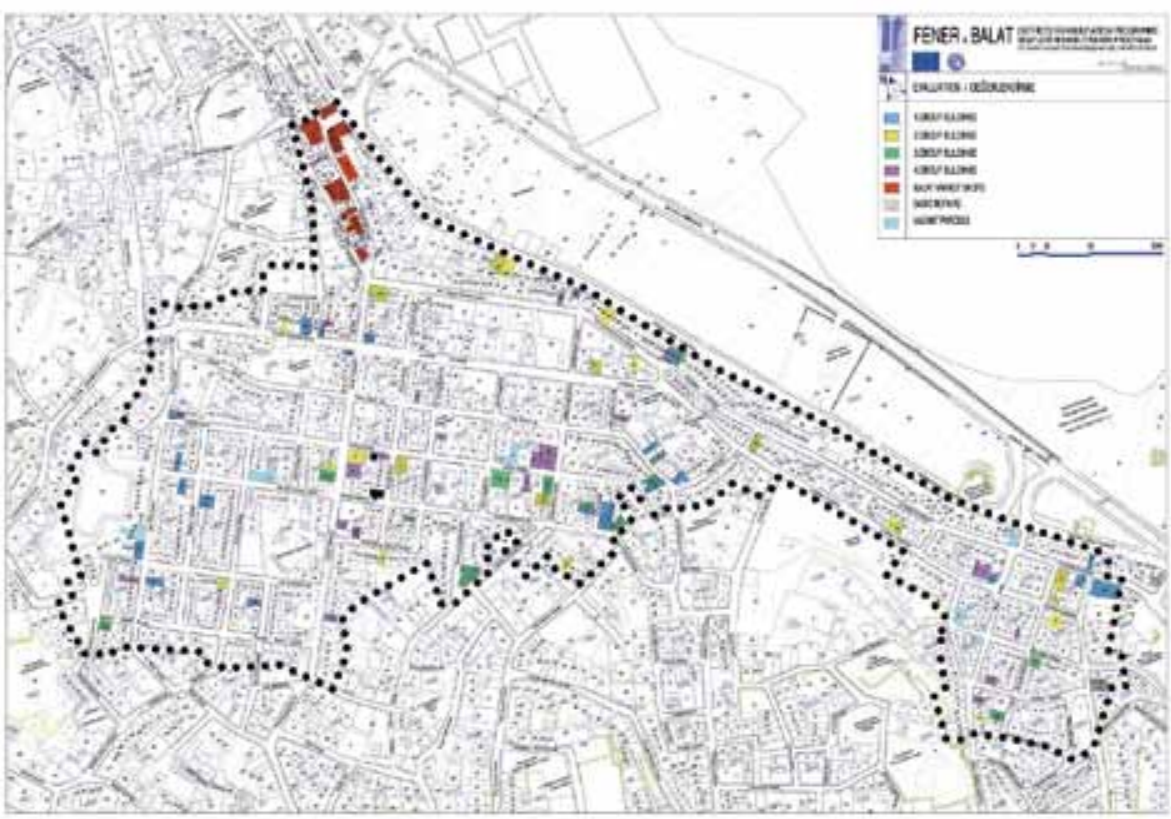

\begin{tabular}{|l|l|}
\hline \multicolumn{2}{|l|}{ FENER BALAT REHABILITATION PROJECT: } \\
\hline PROJECT AREA & 1074 lots (750 of them having historical quality) \\
\hline PROJECT SCOPE & $\begin{array}{l}\text { Restoration of } 121 \text { buildings, Restoration of Historical Balat } \\
\text { Market, Restoration of the Social Center and Dimitri Kantemir } \\
\text { House, Solid Waste Disposal Center }\end{array}$ \\
\hline FEASIBILITY & $1997-1998$ \\
\hline EXECUTION & $2003-2008$ \\
\hline COST & Seven Million $€$ \\
\hline
\end{tabular}

- producing a tender document, issuing the tender and selecting the contractor companies,

- control, coordination and approval of the construction work and progress payments (FBR Program, 2005).

Within the boundaries of the project area, 1074 buildings (744 being of historic character) were evaluated and graded according to a "scoring system" based on the architectural, historical and location value, authenticity, extent of restoration work required, planning issues and seismic risk as well as the willingness and participation of the inhabitants (Altınsay, 2009). The restoration work was divided in two parts being basic repairs for 57 houses and 28 shops in Balat Market and extensive restoration for 27 houses and 5 shops in Balat Market (Dinler, 2013). Within five and a half years, restoration of 121 buildings was completed without displacing the residents; Balat Market, a social center and Dimitri Kantemir House were restored.

The project adopted a meticulous and sensitive restoration approach that aimed to protect the authentic neighborhood fabric. The restoration principles of the project could be summarized as;

- conserving authentic material, architectural and constructional features of the buildings, 
- producing a restoration model and setting a reference for future projects,

- maintaining the residents within the buildings throughout the restoration work,

- achieving sustainability by public participation and attraction of international funds,

- creating work possibilities for residents by improving constructional skills,

- preparing simple repair manuals for residents so as to achieve constant building maintenance,

- simplifying restoration procedures,

- producing a data base and archive for the construction documents (for more information on the physical implementations of FBRP, see Dinler, 2013; FBR, 2005; Altınsay, 2009; 2010-2).

Coming to FBAURP, the project included the urban renewal of Fener, Balat Ayvansaray coast line and fifty nine building blocks up to the historical

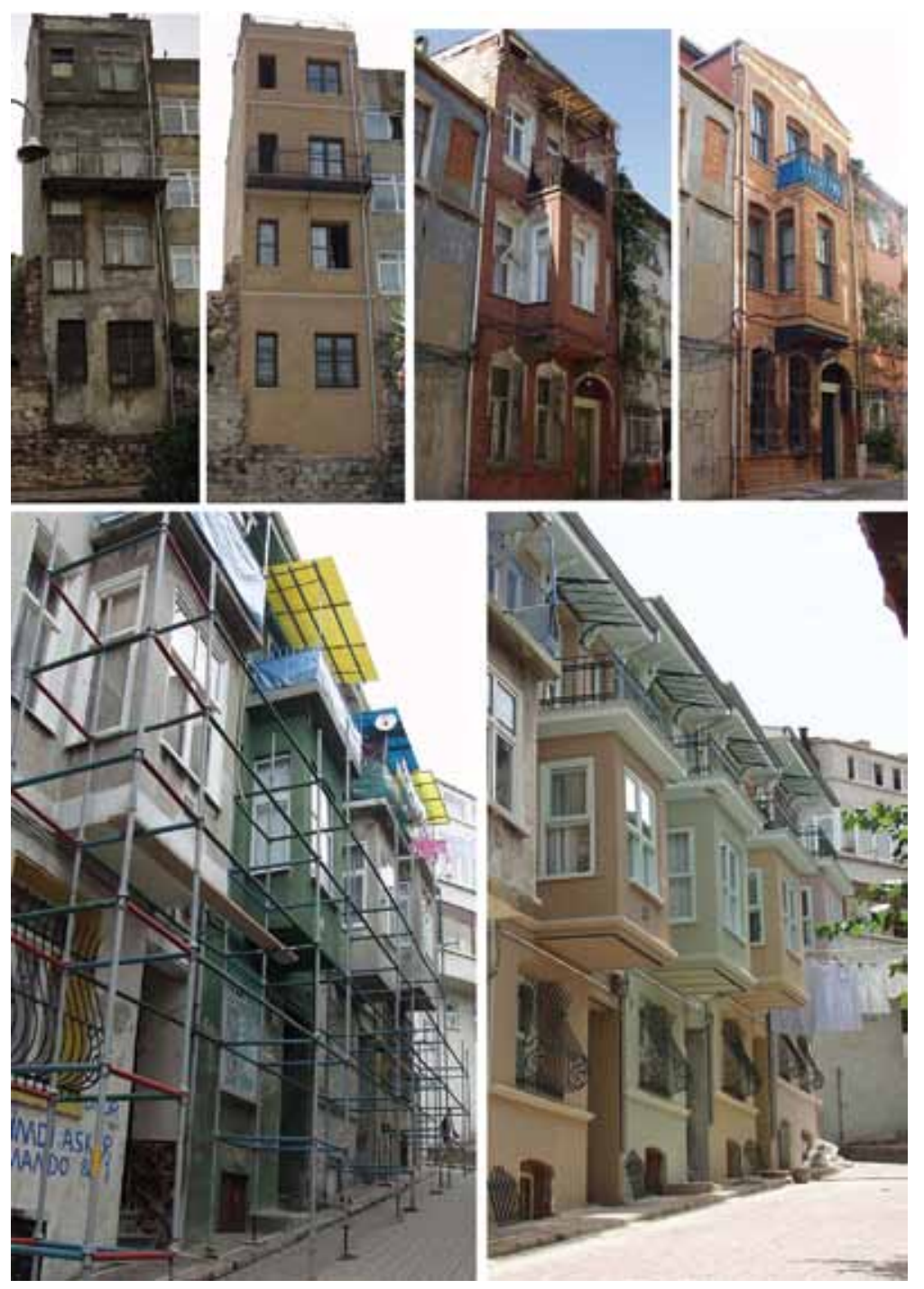


Table 6. Fener Balat Ayvansaray Urban Renewal Project.

Figure 4. The FBAURP Project Area (www. febayder.com)

Figure 5. The FBAURP Site Plan (Project design by Trafo Mimarlık, www.febayder. com).

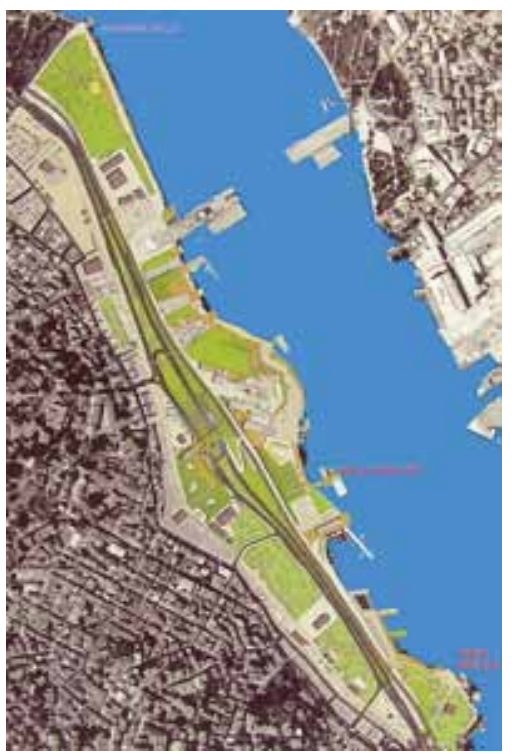

\begin{tabular}{|l|l|}
\hline \multicolumn{2}{|l|}{ FENER BALAT AYVANSARAY URBAN RENEWAL PROJECT } \\
\hline PROJECT AREA & $279.345 \mathrm{~m} 2$ \\
\hline PROJECT SCOPE & $\begin{array}{l}59 \text { building blocks, 909 parcels, 370 registered buildings } \\
\text { at Fener, Balat, Ayvansaray neighborhoods, Golden Horn, } \\
\text { İstanbul. }\end{array}$ \\
\hline PROJECT START & 20 April 2007 \\
\hline PROJECT END & Unknown \\
\hline COST & 200.000 .000 USD \\
\hline CONTRACT SCOPE & $\begin{array}{l}\text { Building Surveys, restoration, restitution, architectural } \\
\text { projects and construction. }\end{array}$ \\
\hline
\end{tabular}

city walls. GAP Company selected eight accomplished architectural offices and formed a board of consultants. The project site was divided according to topography and building typology. Each architectural group picked their site and begun working on the projects. The site plan of the coast line was prepared by Trafo Mimarlık. Çinici Mimarlık was commissioned for four building blocks $(2276,2306,2307,2308)$; Net Mimarlık for three building blocks (2299, 2300, 2305); Teğet Mimarlık for four building blocks, (2644,2645,2830, 2875); HF Mimarlık for one building block (2821); Sepin Mimarlık for two building blocks $(2833,2838)$; Utopya Mimarlık for three building blocks $(2872,2873,2874)$ (Dinler, 2013).

Contrary to FBRP that aims rehabilitation through preservation of the existing urban fabric, FBAURP is bound to make dramatic physical changes in the neighborhoods. First of all, the project rearranges the coast line with additional leisure areas, services and infrastructure such as terraces, playgrounds, sports facilities, urban furniture, decks, pedestrian routes, car parking and new marinas for small sized boats. Moreover, the neighborhoods are attempted to be re-connected to the coast line with an overcrossing.

Apart from the coast line, the most radical change the project brings to the area is the transformation of the urban pattern through the amalgamation of 317 lots (of which 108 lots are registered) on 17 building blocks;

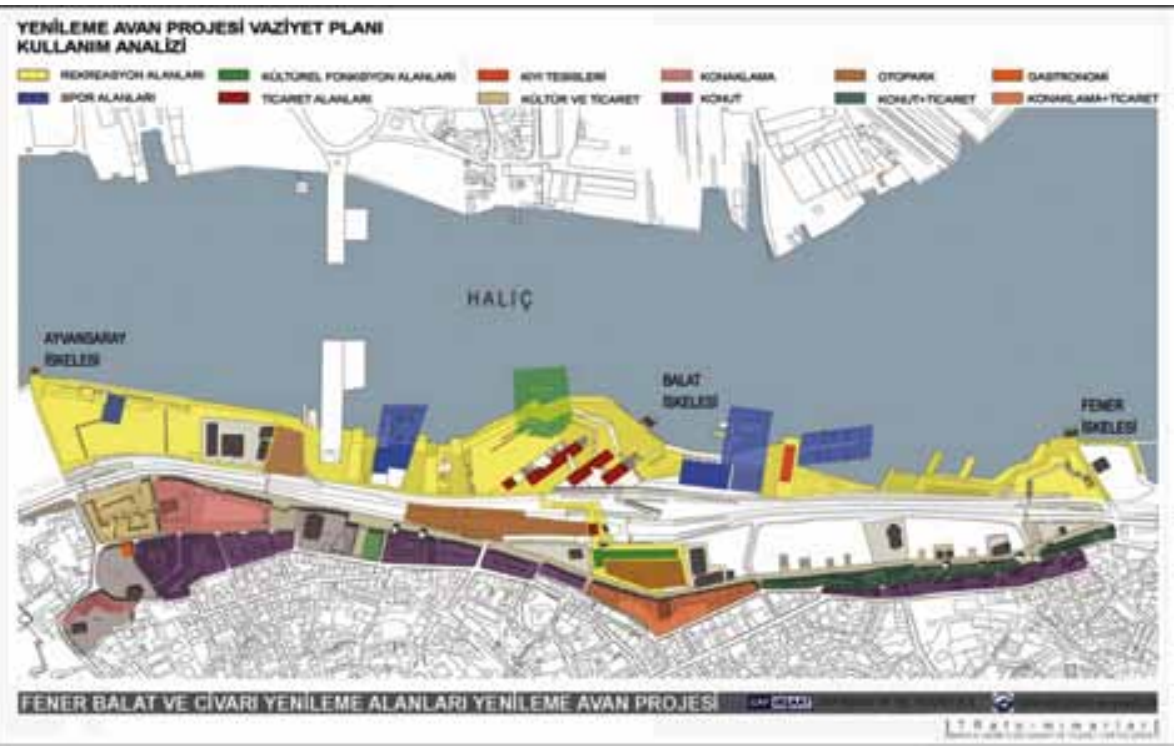


Figure 6. The FBAURP Site Perspectives (Project design by Trafo Mimarlık, www. febayder.com).

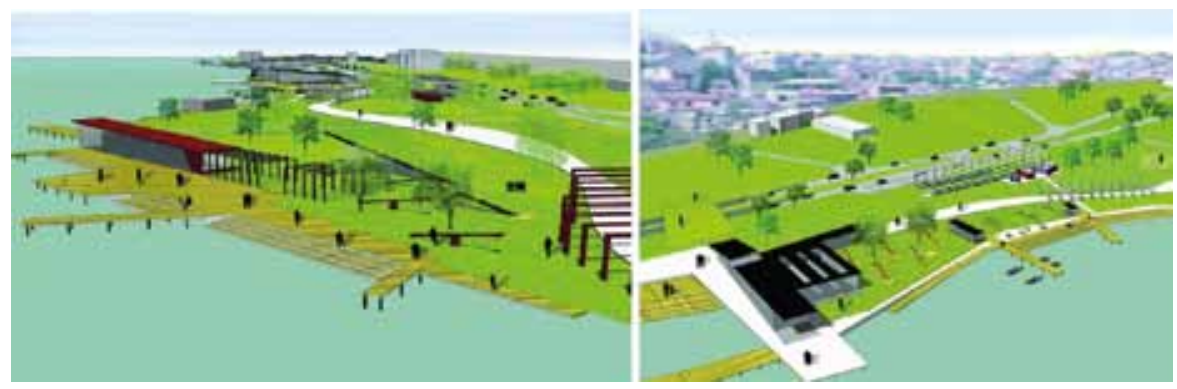

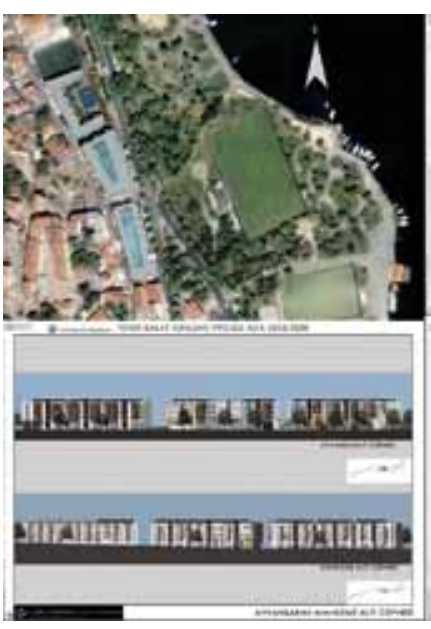

Figure 7. Transformation of the Urban Pattern Through Amalgamation of Building Lots (www.sepinmimarlık.com)

Figure 8. Transformation of the Street Character Through Construction of New Facades (www.cinicimimarlik.com)
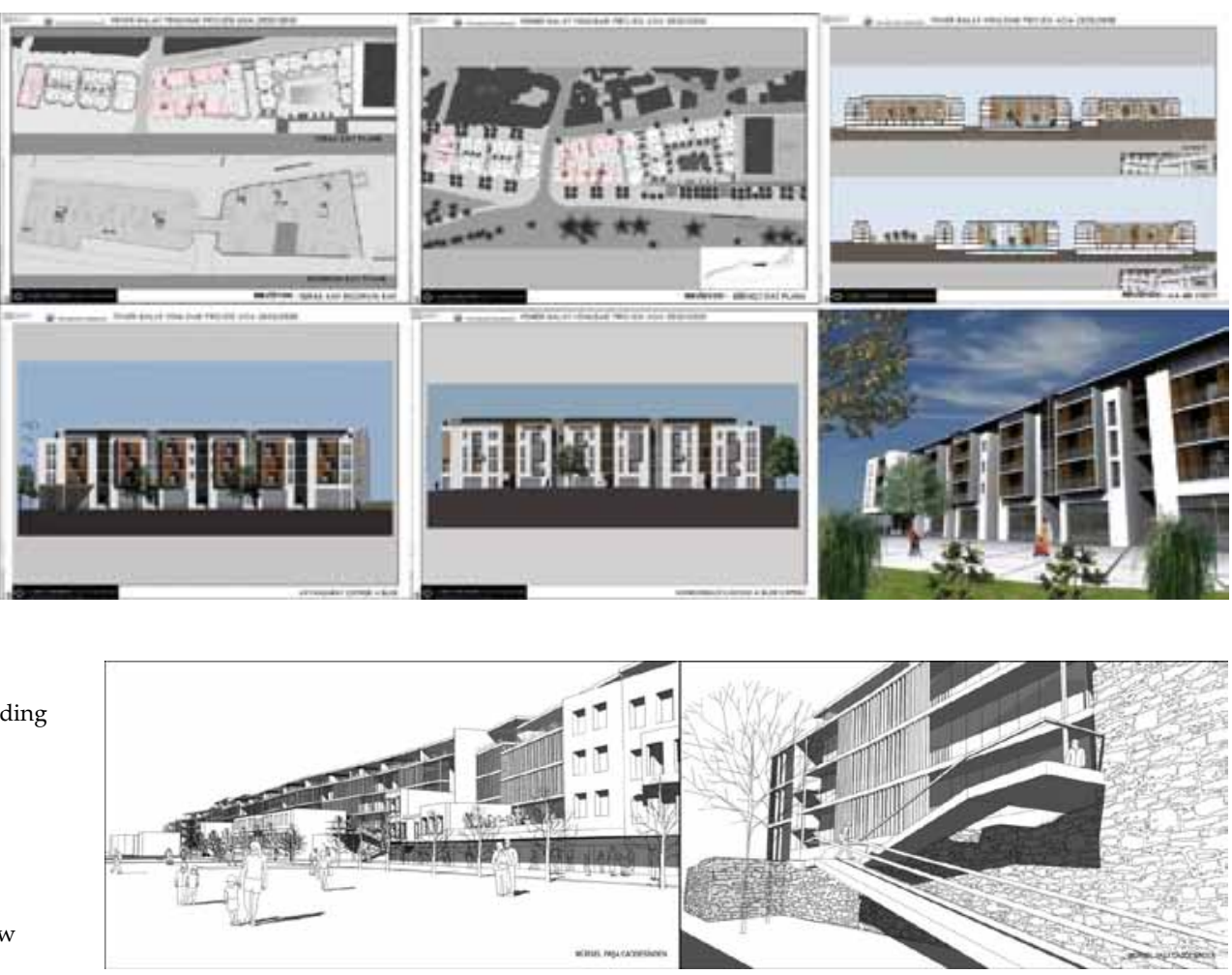

producing 103 new lots (Dinler, 2013). The planar arrangements of the lots are altered so as to produce larger footprints.

Furthermore, some of the lots are transformed functionally. Altering the existing residential fabric, new functions requiring large footprints such as conference halls, movie theatres, exhibition halls and commercial buildings are inserted. In the project booklet, it is stated that $\% 2$ of the project area is designated to cultural use; involving the construction of new complexes and recreational areas; $\% 12$ for commercial use, $\% 16$ for hotels and $\% 8$ for office use (Eken, 2010).

The authentic street character is also transformed by the project through storey additions to the buildings, use of new materials and construction of new facades. In fact, FBAURP has a contradicting understanding of restoration, renovation and reconstruction as architectural intervention techniques. The redesign of planar schemas and elevations are defined as "restoration", the redesigning of planar schemas while conserving the 
Table 7. Physical Implementation of FBRP and FBAURP.

\begin{tabular}{|l|l|l|}
\hline Open Spaces & FBRP & FBAURP \\
\hline $\begin{array}{l}\text { No particular implementations with regards } \\
\text { to open spaces }\end{array}$ & Reorganization of the coastline \\
Buildings Criteria Of & $\begin{array}{l}\text { Physical and social criteria + participation of } \\
\text { the residents }\end{array}$ & Physical criteria \\
\hline $\begin{array}{l}\text { Architectural } \\
\text { Intervention } \\
\text { Understanding }\end{array}$ & $\begin{array}{l}\text { Repairing the existing buildings with } \\
\text { minimum invasion, protecting the authentic } \\
\text { fabric and architecture }\end{array}$ & $\begin{array}{l}\text { Transformation of the physical and } \\
\text { social fabric }\end{array}$ \\
\hline Function & $\begin{array}{l}\text { Original functions of the buildings are } \\
\text { preserved }\end{array}$ & $\begin{array}{l}\text { There are functional changes in the } \\
\text { land use }\end{array}$ \\
\hline
\end{tabular}

elevations are defined as "renovation" and the construction of the replicas of historic buildings are defined as "reconstruction" (Eken, 2010).

Lastly, the implementation areas of the two projects intersect, meaning the latter project intervenes with some of the buildings already evaluated and restored by the prior project (Altınsay, 2010). This is a clear indicator of the fact that two consecutive projects, initiated by the same institution being FM, problematizing the same area have no correspondence, no data sharing or cooperation whatsoever. In the ICOMOS UNESCO Report in 2009, this issue was addressed and the focus of FBAURP on land development rather than conservation of historic buildings was stated to be "inappropriate in World Heritage core areas" (ICOMOS/UNESCO, 2009).

Social Implementations

Social rehabilitation of the neighborhoods was a crucial part of FBRP. In this respect, the project incorporated a Social Center with a health clinic, nursery, educative classes and a mother and child center. Two buildings including the Dimitri Kantemir House were restored in order to function as Social Centers for the neighborhoods (Altınsay, 2009). Human Resource Development Foundation (İnsan Kaynaklarını Geliştirme Vakfı - HRDF) and Cultural Consciousness Development Foundation (Kültür Bilincini Geliştirme Vakf 1 ) were assigned for the operation of the center and the activities have started in 2006. Within the scope of the program, a childcare center was established; seminars and focus group discussions, targeting mainly women were organized; 39 seminars were conducted with the participation of 331 women and 215 adolescents. Individual counselling concerning family and health issues were provided for the inhabitants. Educational activities such as computer, English and Math courses for primary school students were organized. A program named parent school partnership was established. Lastly, occupational training was provided for women (Final Report of HRDF, 2007).

In terms of participation, the program established a Community Forum for direct inhabitant involvement. Community volunteers have been selected as representatives that could act as the local voice (Altınsay, 2010). A series of meetings involving the Advisory Board members and community volunteers were held in order to develop communication and cooperation. Moreover, the program set forth the goal of active participation of the residents to restoration works in order to achieve sustainability of the building maintenance as well as the acquirement of skills that would provide an economic input to the area. That way, it aimed to rehabilitate the physical structure of the area while providing a model that contributed to local economy.

Finally, in terms of ownership patterns, FBRP deliberately aimed to avoid gentrification and displacement. The main objective of the project was "to 
Table 8. Social Implementations of FBRP and FBAURP.

\begin{tabular}{|l|l|l|}
\hline & FBRP & FBAURP \\
\hline $\begin{array}{l}\text { Social } \\
\text { Rehabilitation }\end{array}$ & $\begin{array}{l}\text { Extensive social rehabilitation } \\
\text { agenda }\end{array}$ & $\begin{array}{l}\text { No social rehabilitation } \\
\text { agenda }\end{array}$ \\
\hline Participation & $\begin{array}{l}\text { Community forum, active } \\
\text { participation to restoration } \\
\text { works as an economic input }\end{array}$ & No participation incentive \\
\hline $\begin{array}{l}\text { Ownership } \\
\text { patterns }\end{array}$ & $\begin{array}{l}\text { Aim to keep the inhabitants in } \\
\text { place }\end{array}$ & $\begin{array}{l}\text { Aim to transform the } \\
\text { ownership structure }\end{array}$ \\
\hline
\end{tabular}

make the people who have been living in the area for a long time, having no means to improve the buildings by themselves, primary beneficiaries of the restorations" (FBR Program, 2005). To minimize gentrification, the owners of the buildings to be restored signed an agreement stating that they would not sell their property for five years. Moreover, the restoration works were completed without removing the residents from the buildings.

Coming to FBAURP, there is no intention for social implementations. The project does not involve new public services or a social center. There are no social criteria in the selection of the buildings to be altered. In terms of participation, the inhabitants are excluded from the preparation stages of the project; not being informed about the decisions made for their neighborhood, about their homes (FEBAYDER, 2009). Moreover, the project has no strategy to keep the inhabitants in the neighborhood. Quite the contrary, the project agenda is based on profit generation by displacement of the existing demography with a higher income level group of new comers. The FBAURP booklet states that property owners should participate in the project and if they cannot afford the construction expenditures, they should move (Eken, 2010). Furthermore, the project has no strategy for the tenants; considering only property owners as a negotiating party and disregarding the dwelling rights of the tenants.

In short, FBAURP has no social implementations. Yet, the physical transformation of the area intended by the project will inevitably bring a new socio-economic structure and an ownership pattern to the neighborhood.

\section{Impacts of the Projects}

FBRP is a small scaled and humble project that prioritized public welfare and participation, intending to ameliorate the life quality of the area without causing dramatic economic ruptures. The project accommodated point interventions and creative solutions that aimed the utilization of local potential and labor force. Quite the contrary, FBAURP is an ambitious and large scale physical intervention that could inevitably alter the neighborhoods physically and socially. Below, the impacts of the projects are discussed. As FBAURP is not executed yet, the impact assessment will be made through future projections and discussion of public reactions against the project.

Physical Impacts

The physical impacts of FBRP are limited in parallel with its humble scale. The project could be evaluated as successful in terms of individual restoration. Inhabitants were content with the simple or extended repairs of the 121 buildings (Altınsay, 2010). On the other hand, the discontinuity and lack of coherency of the project have been disappointing for the 
community (Eken, 2010, Enlil and Bilen, 2009). Due to limited time and budget as well as lack of political support, the project could not achieve an adequate number of restorations that could create a sense of continuity and comprehensiveness. The buildings were restored individually and selected in a scattered fashion throughout the project area. The reason for this manner of selection was to avoid the beautification of a single street and trigger further restoration efforts. Yet, the modest number of restoration work was not enough to achieve an integrated visual impact. Furthermore, no intervention could be done in terms of open space. Initially, the existing empty lots within the urban fabric were planned to be reutilized as small public spaces for women and children; yet this idea could not be realized (Altınsay, 2009). Even though the inhabitants use the coast line more frequently due to a cleaner and safer environment, neighborhoods still lack playgrounds and sports areas for children (Eken, 2010). As a result, the work that has been done could not achieve an obvious physical improvement of the neighborhoods.

In terms of utilities and services, the installment of waste disposal system was successful as the neighborhood became cleaner (Eken, 2010; Enlil and Bilen, 2009). On the other hand, the night lighting of the neighborhoods is still inadequate, creating a feeling of unsafety at night.

Despite the limited impact of FBRP, FBAURP is bound to create an irreversible physical transformation of the authentic historical residential fabric of the neighborhood; due to amalgamation of lots, alteration of planar and elevation compositions of buildings, introduction of new building materials, production of new streetscapes and change of function; as discussed in the previous chapter. The project has an extensive agenda in terms of open space; proposing new recreational and service facilities to the coastline and connecting the neighborhoods to the waterfront. Although the intention is valid and necessary for the community, the target group of this intervention is unclear as the project aims to alter the demography of the area.

\section{Social Impacts}

The social impacts of FBRP are twofold. The first impact is the social rehabilitation of the area through the establishment of a Social Center. As discussed in the previous chapter, a social center was established and activated in the course of the project. Yet, the efficiency and sustainability of the center is debatable (Altınsay, 2010). Although there was a considerable increase in the satisfaction of health and education services, the capacity and public communication of the center was claimed to be insufficient. The municipality was inadequate in efficiently managing the center and developing viable strategies to sustain social improvement (Eken, 2010). Dimitri Kantemir House; restored for the purpose of being another social center; was never put into action by the FM. Moreover, the community was not adequately informed about the activities of the center as many of the inhabitants were unaware of the activities and services provided.

The second and greater social impact of the project is the enhancement of public awareness and participation. The project became a means of underlining the historical value of the area, raising consciousness about environment, community and civic rights of the inhabitants. This result could be derived from the community reflex generated towards the consecutive project in the area, being FBAURP. 
FBAURP on the other hand, is a striking example displaying the shortcomings of the urban transformation processes based on Law 5366. First of all, transferring the negotiation of the property rights of citizens to a private enterprise is highly problematic. It is a fact that numerous urban renewal and transformation processes incorporate public - private collaborations. Yet, these processes become socio-economically and legally problematic when they are left solely in the hands of the private sector with a profit based agenda of physical transformation, lacking social and public perspective. The social policies of urban transformation should clearly be defined by laws and regulations. It is the duty of the urban government to produce social policies that protect the legal rights of the citizens as well as the authenticity of the physical and cultural texture of the neighborhoods. The statement of the Fener Balat Association below clearly indicates the basis of the problem: "Our homes with deeds belonging to us were taken into the scope of urban renewal without our knowledge or consent. They were commissioned to a private firm that prepared the projects. This is a violation of our dwelling and property rights" (FEBAYDER, 2009). In this respect, the major social impact of FBAURP, prior to implementation has been the emergence of a civil revolt against the project.

\section{Public Reaction}

The public reaction towards the FBRP was twofold. In the beginning of the project, most of the residents were skeptical, mainly because of mistrust towards initiating institutions. Since the public relations of the project could not be effectively conducted, there was a great deal of misinformation (Altınsay, 2010). As the project proceeded and restoration work became visible, the inhabitants began to have a more accurate idea about the goals and agenda of the project. After the termination, the reactions toward the project were generally positive yet the main public opinion was disappointment towards the limited scope and impact of the project, as discussed previously.

The public reactions toward FBAURP, on the other hand were quite harsh and protesting. First of all, the public communication of the project was problematic. Residents were not informed about the process until a project meeting was held by FM in July 2009; two years after the initiation. In this meeting, the preliminary projects were ill received by the residents as they were perceived as displacement projects that would force them out of the neighborhoods. The existing urban texture had gone through major transformation in the projects presented (FEBAYDER, 2009). The footprints of the blocks were changed and enlarged; individual blocks were merged together for the sake of having larger floor areas; making it impossible for the land owners to reclaim their property. Following this presentation, the residents formed the Fener Balat Association to claim and protect their neighborhood and legal rights. As a result of the legal action taken by the association, the project was cancelled by the İstanbul Fifth Court of Law in June 2012. The basis for this decision was that the project destroyed the neighborhood culture, disregarded the existing social structure and urban texture of the area, harmed the historical fabric as registered cultural heritage buildings were intended to be demolished against the rulings of the board of preservation. Following this cancellation, an "urgent expropriation" ruling was issued by the ministerial cabinet in $7^{\text {th }}$ of October 2012, as a result of the demand of FM. This ruling was based on the twenty seventh article of the Expropriation Law that enables the confiscation and demolishing of private property, under extraordinary circumstances such 


\begin{tabular}{|c|c|c|}
\hline & FBRP & FBAURP \\
\hline Physical Impacts & $\begin{array}{l}\text { Limited amount of restoration } \\
\text { work, could not achieve an } \\
\text { obvious physical improvement } \\
\text { of the neighborhoods }\end{array}$ & $\begin{array}{l}\text { Irreversible physical } \\
\text { transformation of the } \\
\text { authentic historical residential } \\
\text { fabric of the neighborhood }\end{array}$ \\
\hline Social Impacts & $\begin{array}{l}\text { Limited improvement in the } \\
\text { social services, enhancement } \\
\text { of public awareness and } \\
\text { participation }\end{array}$ & $\begin{array}{l}\text { Emergence of a civil revolt } \\
\text { against the project }\end{array}$ \\
\hline Public Reaction & $\begin{array}{l}\text { Positive yet disappointing due } \\
\text { to the limited scope and impact }\end{array}$ & $\begin{array}{l}\text { Harsh and protesting public } \\
\text { reaction leading to an ongoing } \\
\text { legal battle }\end{array}$ \\
\hline
\end{tabular}

as war or natural disasters. The Plato Academy was one of the buildings subjected to "urgent expropriation". The academy issued a lawsuit against urgent expropriation and the lawsuit resulted in the suspension of execution, granted by the Council of State. This decision; being the first ruling against a ministry issued expropriation in the history of Turkish Republic; became a valuable precedent for not only the cases regarding the neighborhood but also all the historical districts under the threat of destruction due to the Law 5366.

The current state of the project is a domain of conflict between the urban government that undermined the court order and the residents that are determined to protect their rights. The process is halted and the related architectural firms have retrieved from the process. The FM is currently working on an alternative project with a new architectural team; yet there are no official statements about the issue. Time will show the outcome of this legal battle that produced a reflex of civil rights which could potentially become a future reference for other urban transformation processes.

\section{CONCLUSION}

Two projects discussed above represent acutely different approaches to the reproduction of historical residential areas in İstanbul. On one hand, FBRP is a non-profit approach, aiming to create a physically, economically and socially self-sustaining urban environment while keeping the land values stable. The model tries to resist gentrification and urban displacement; aiming to distribute the generated value back to the inhabitants. Instead of a harsh socio-economic shift, a slower yet less dramatic improvement in the area is proposed. The shortcomings of this project are the limited physical and social impact due to insufficient coordination, insufficient budget and lack of support from the local government. Although the success of the final outcome is debatable, FBRP suggests a viable urban rehabilitation model open for improvement. However, the project model which achieved a certain level of success was not adopted, improved and institutionalized by the local authorities as an urban intervention method for successive implementations.

Quite the contrary, most of the projects in İstanbul within the last five years, including FBAURP are profit oriented implementations, lacking social dimension. With a lavish budget, a large project area, an unlimited support from FM and a distinguished technical team of well-known architectural firms and specialized consultants, FBAURP is properly funded and coordinated. Yet, the profit-based build and sell model of 
6. For additional information on urban governance models, see: Şen, 2014; Şengül, 1999, 2003. the project and the absence of a social agenda could result in acute and traumatic changes for the neighborhoods. Gentrification and displacement are expected outcomes of the implementation and the resident's share from the rent value produced will be minimal.

From the analysis of the two cases, a number of hints for a viable urban interference model could be derived as stated below:

- The identity of the involved actors is a key factor. A multiactored structure involving the collaboration of a non-profit actor introducing an agenda of public welfare, a governmental organ controlling, regulating and subsidizing the process and the private sector injecting know how, practicality and problem solving skills is required (6).

- Financial model could involve subsidizing from a governmental agent or an NGO; yet a self -sufficient and sustainable financial model is necessary for avoiding a profit based project agenda.

- The legislative basis of urban transformation in Turkey should be readdressed; social and legal shortcomings of the current laws should be reformulated.

- The scope and agenda of urban transformation processes should incorporate sustainable social and economic policies for the inhabitants as well as comprehensive physical rehabilitation of the area that could create a coherent spatial impact.

- The project should have consistent political support in order to foresee the achievement of goals and sustain the implementations.

- Adequate control and supervision structures should be assigned in order to achieve a transparent and accountable process.

- Effective public communication and active participation should be achieved throughout the project.

- Physical implementations should adopt a sensitive restoration approach protecting the authentic urban fabric as well as architectural peculiarities of the buildings.

- Social implementations should be well communicated and sufficiently distributed throughout the project area. Persistence after the implementation stage is important for achieving results.

- Lastly, urban transformation should target the greater public welfare instead of the profit of a privileged few. Urban strategies that aim to minimize gentrification and displacement should be an integral part of the project scope.

The revitalization of coastal areas that carry historical and geographical significance, like the Golden Horn, is not only affirmative but also inevitable. Yet, the reductionist and profit oriented approaches carry the danger of producing greater problems than they intend to solve. In fact, urban renewal implementations in Turkey tend to become state driven destruction mechanisms in line with the dynamics of the real estate market. The key to applying viable transformation strategies are to develop participative and multi-layered action plans; learning from past experience and transfer the accumulated data into future implementations. In this context, the primary duty of urban governments is the production of efficient yet transparent action plans that primarily protect the rights of the citizens. 


\section{BIBLIOGRAPHY}

ALTINSAY, B. (2010) Personal interview, $5^{\text {th }}$ of June 2010, İstanbul.

ALTINSAY, B. (2009) Fener Balat Districts Rehabilitation Program: Revitalizing Buildings and Keeping the Locals Comfortably at Home: Is It Viable?, International Symposium IAPS-CSBE EIAPSHOUSING Network, Revitalizing Built Environments: Requalifying Old Places for New Uses, İstanbul Technical University, İstanbul.

ALTINSAY, B. (2010-2) Bir Kentsel İyileştirme Deneyiminin İçinden: Fener ve Balat Semtleri Rehabilitasyon Program1, Kentsel Dönüşümde Politika, Mevzuat, Uygulama: Avrupa Deneyimi, İstanbul Uygulamaları, der. D. Özdemir, Nobel, Ankara; 369-98.

ALTINTAŞ, S. (2012) Kentsel Dönüşüm Sürecinde İktidarın Meşrulaştırıcı Söylemi: Depremin Hegemonik Şiddeti, Birikim Dergisi, http://www. birikimdergisi.com/birikim/makale.aspx?mid=898, Access Date (15.09.2014).

ATAÖV, A., OSMAY, S. (2007) Türkiye'de Kentsel Dönüşüme Yöntemsel Bir Yaklaşım, ODTÜ Mimarlık Fakültesi Dergisi, 24(2) 57-82.

AYSEV, E. (2012) Kentsel Mekan Üretim Süreçlerinde Mimarın Rolü: İstanbul Örneği, yayınlanmamış Doktora Tezi, İTÜ, İstanbul.

AYSEV, E., AKPINAR. İ. (2009) The Reproduction of Space in Global İstanbul: Golden Horn Cultural Valley Project, IAPS 2009, İTÜ, İstanbul.

BARTU CANDAN, A., KOLLUOĞLU, B. (2008) Emerging Spaces of Neoliberalism: A gated Town and a Public Housing Project in İstanbul, New Perspectives on Turkey, (39) 5-46.

BEZMEZ, D. (2009) The Politics of Urban Waterfront Regeneration: The Case of Haliç (the Golden Horn), İstanbul International Journal of Urban and Regional Research, http://onlinelibrary.wiley.com/ doi/10.1111/j.1468-2427.2008.00825.x/full, Access Date (09.8.2014).

BRENNER, N., THEODORE, N. (2004) Cities and the Geographies of Actually Existing Neoliberalism, Spaces of Neoliberalism: Urban Restructuring in North America and Western Europe, N. Brenner and N. Theodore (ed. By), Blackwell Publishers.

BOURDIEU, P. (2003) Counterfire: Against the Tyranny of the Market, Verso Books, London.

BOURDIEU, P. (1999) Acts of Resistance: Against the Tyranny of the Market, New Press, N.Y.

CHOMSKY, N. (1999) Profit over People: Neoliberalism and Global Order, Seven Stories Press.

ÇAVUŞOĞLU, E. (2011) İslamcı Neo-Liberalizmde İnşaat Fetişi ve Mülkiyet Üzerindeki Simgesel Hale, İnşaat Ya Resullallah, Birikim Dergisi, (270) 40-51.

DINLER, M. (2013) Impact Assessment of Major Urban Interventions on the Cultural Heritage of Fener and Balat Districts, Unpublished Master Thesis conducted by Şahin Güçhan, N., METU Graduate Program of Restoration, METU, Ankara. 
DUZCU S. (2006) The Assessment Criteria of Urban Regeneration Projects: The Case of Fener Balat Districts Program in İstanbul, Unpublished Master Thesis conducted by Akkar, Z.M., METU Graduate Program of Restoration, METU, Ankara.

EKEN, T. (2010) Gentrification in Fener Balat Neighborhoods: The Role of Involved Actors, Unpublished Master Thesis conducted by Ataöv, A., METU Graduate Program of City and Regional Planning, METU, Ankara.

EKMEKÇİ, O. (2012) Neoliberal Urbanization In the Case of İstanbul: Spatial Manifestations and Ways of Contesting It, Unpublished Master Thesis, $\mathrm{KTH}$, Stockholm.

ENLİL Z., BİLEN Ö. (2009), The Impact Analysis of UNESCO's Project in Fener and Balat Districts.

FATIH MUNICIPALITY, EUROPEAN UNION, UNESCO, FRENCH INSTITUTE FOR ANATOLIAN STUDIES (1998) The Rehabilitation of Balat and Fener Districts, Analysis and Regulation Proposals, İstanbul.

FATIH MUNICIPALITY (2011) Fatih Municipality Official Web Site. [http:// www.fatih.bel.tr/bp.asp?caid=631] Access Date (12.01.2011).

FBR PROGRAM (2005) Fener Balat Rehabilitation Program Official Web Site. [http://www.fenerbalat.org] Access Date (02.01.2012).

FEBAYDER (2009) Fener Balat Ayvansaray Mülk Sahiplerinin ve Kiracılarımın Haklarını Koruma ve Sosyal Yardımlaşma Derneği Official Web Site [http://www.febayder.com/] Access Date (13.06.2011)

GAP CONSTRUCTION (2007) GAP Construction Official Web Site [http:// www.gapinsaat.com/en/URBalat.aspx] Access Date (12.06.2011)

GÜLÖKSÜZ, E. (2002) Negotiation of Property Rights in Urban Land in İstanbul, International Journal of Urban and Regional Research, (26).

GÜNAY, Z. (2013) Renewal Agenda in İstanbul: Urbanisation vs. Urbicide, $49^{\text {th }}$ ISOCARP Congress, Brisbane, Australia.

HABITAT REPORT (1996) Report of the United Nations Conference on human Settlements, United Nations, İstanbul.

HARVEY, D. (2005) A Brief History of Neoliberalism, Oxford, N.Y.

HARVEY, D. (2006) On Neoliberalism: An Interview with David Harvey by Sasha Lilley, MRzine, [http://mrzine.monthlyreview.org/2006/ lilley190606.html] Access Date (19.06.06)

HARVEY, D. (2008) The Right To The City, New Left Review, (53).

ICOMOS / UNESCO (2006) The World Heritage Site of İstanbul Screening Report, TMMOB Chamber of Architects İstanbul Greater City Branch, İstanbul.

ICOMOS / UNESCO (2009) Report on the Joint UNESCO World Heritage Centre / ICOMOS Reactive Monitoring Mission to the World Heritage Site of Historic Areas of İstanbul.

KEIL, R. (2002) Common-Sense Neoliberalism: Progressive Conservative Urbanism in Toronto, Canada, Antipode, 34(3) 578-601.

KEYDER, Ç. (2000) İstanbul: Küresel İle Yerel Arasında. Metis, İstanbul.

KIVIRCIK, N. (2010) Personal interview, $5^{\text {th }}$ of June 2010, İstanbul. 
KURTULUŞ, H. (2005) Giriş, İstanbul'da Kentsel Ayrışma, Ed. H. Kurtuluş, Bağlam, İstanbul; 9-24.

KURTULUŞ, H. (2006) Kentsel Dönüşüme Modern Kent Mitinin Çöküşü Çerçevesinden Bakmak, Planlama, 2(36) 7-13.

KUYUCU, T. (2009) Poverty, Property and Power: Making Markets in İstanbul's Informal Low-Income Settlements, Unpublished Ph.H Dissertation, University of Washington, Seattle WA.

KUYUCU, T., ÜNSAL, Ö. (2010) Urban Transformation as State-Led Property Transfer: An Analysis of Two Cases of Urban Renewal in İstanbul, Urban Studies, 47(7) 1479-99.

LEFEBVRE, H. (1996) Writings on Cities. Ed. Kofman, Lebas. Blackwell, Oxford.

MADRAN, E. (2005) Kültür Ve Tabiat Varlıklarını Koruma Mevzuatındaki Son Düzenlemeler, Korumada 50 yıl Sempozyumu Bildiriler Kitabı, MSGSÜ, İstanbul, 245-55.

ÖKTEM, B. (2005) Küresel Kent Söyleminin Kentsel Mekanı Dönüştürmedeki Rolü: Büyükdere - Maslak Aksı, İstanbul'da Kentsel Ayrışma, Ed. H. Kurtuluş, Bağlam, İstanbul, 25-76.

ÖKTEM, B. (2011) İstanbul'da Neoliberal Kentleşme Modelinin SosyoMekansal İzdüşümleri, İ̈ Siyasal Bilgiler Fakültesi Dergisi, (44) 23-40.

ÖZDEMİR, E. (2013) Contesting Neoliberal Urbanization: Contemporary Urban Movements in İstanbul, the Case of Gülsuyu - Gülensu Neighborhoods, Unpublished PhD Thesis, METU, Ankara.

SULUKULE PLATFORMU (2009) Sulukule Platformu Official Web Site [http://sulukuleyasasin.blogspot.com/] Access Date (02.01.2011).

ŞAHIN GÜÇHAN, N., KURUL, E. (2009) A History of the Development of Urban and Architectural Conservation in Turkey: From The Mid19th Century Until 2004, METU Journal of Faculty of Architecture, 26(2) $19-44$.

ŞEN, B. (2006) Ekonomik Gelişmenin Kültürel Stratejileri: İstanbul Kent Merkezleri ve Tarihi Kentsel Alanların Yeniden Yapılandırılması, Planlama, 2(36) 65-77.

ŞEN, A. F. (2014) Neoliberalizm Sürecinde Kentsel Mekanların Dönüşümüne Kamusal Müzakere ve Halkla İlişkiler Açısından Bakış, Çağdaş Yerel Yönetimler, 23(2) 1-25.

ŞENGÜL, T. (1999) Yerel Yönetim Kuramları: Yönetimden Yönetişime, Çă̆daş Yerel Yönetimler, 8(3) 3-19.

ŞENGÜL T. (2003) Yerel Devlet Sorunu ve Yerel Devletin Dönüşümünde Yeni Eğilimler, Praksis, (9) 187-97.

ŞENGÜL, T. (2009) Kentsel Çelişki ve Siyaset: Kapitalist Kentleşme Süreçlerinin Eleştirisi, İmge, Ankara.

ŞİŞMANYAZICI, B.; TURGUT YILDIZ, H. (2010) Tarihi Kentsel Alanlarda "Toplumsal ve Mekansal Yeniden Yapilanma": Fener ve Balat Örneği, Mimarlık, (352).

TEKELİ, I (2011) Kent, Kentli Hakları, Kentleşme ve Kentsel Dönüşüm, Tarih Vakfı, İstanbul. 
Alındı: 28.01.2014; Son Metin: 11.11.2014

Anahtar sözcükler: Kentsel mekan üretimi; Neoliberal kentleşme politikaları; İstanbul; Haliç.
TMMOB CITY PLANNERS BOARD OF DIRECTORS (2006) Kentsel Dönüşüm Değil, Rant Amaçlı Tasfiye Yasası, Planlama, 2(36) 5-7.

TOURAINE, A. (2001) Beyond Neoliberalism, Wiley.

ÜNSAL, Ö. (2011) (Y1k1larak) Yeniden Kurulan Kent: 2000'li Y1lların İstanbul'u, Betonart, (29).

UÇAR, E. (2010) Personal interview, $15^{\text {th }}$ of March 2010, İstanbul.

YALÇINTAN, M. C. (2005) Globalization, Local Politics and Planning Decisions: The Case of Koç University in İstanbul, unpublished PhD Thesis, London School of Economics, London.

YIRTICI, H. (2005) Çă̆daş Kapitalizmin Mekansal Örgütlenmesi, İstanbul Bilgi Üniversitesi Yayınları, İstanbul.

ZUKIN, S. (1998) Urban Lifestyles: Diversity and Standardization in Spaces of Consumption, Urban Studies, 35(5-6) 825-39.

\section{0'LERIN ISSTANBUL'UNDA TARIHHI MERKEZIN YENIDEN ÜRETIMI: FENER - BALAT'TA İKI PROJE ÜZERINDEN ELEŞTİREL BIR OKUMA}

2000'li yılların İstanbulu, yoğun kentsel mekan üretimi ve yeniden üretimi süreçlerine sahne olmaktadır; neredeyse tüm şehrin kesintisiz bir şantiyeye dönüştüğü söylenebilir. Bir yanda kentsel alanın sınırları yeni konut bölgeleri ve merkezi iş alanlarıyla genişlerken, öte yanda kent merkezinde yoğunlaşan kentsel dönüşüm projeleri soru işaretleri yaratmaktadır. Dahası, kentin müşterek belleğinde yer etmiş kültürel, tarihi ve doğal kentsel simgeler, mekanın kapitalistleşmesi adına yeniden şekillendirilmekte ve şehir peyzajı önemli sayıda can alıcı müdahaleye maruz kalmaktadır. Kısacası günümüz İstanbulu, kentin dokusunu geri dönülemez bir biçimde dönüştürmekte olan bir dizi büyük ölçekli uygulamanın nesnesidir.

2000'li yılların İstanbulunda ana akım kentsel mekan üretim pratikleri, küresel sermaye, merkezi ve yerel otoritelerin işbirliği içinde benimsedikleri neoliberal kentsel politikalar doğrultusunda şekillenmektedir. Bu pratikleri çözümleyebilmek için öncelikle 2000'li yılların kentsel politikalarının anlaşılması önemlidir. Bu çalışma, İstanbul'un tarihi merkezindeki mekansal üretim süreçlerine; 2000'li yıllarda Haliç bölgesinde ardışık olarak gündeme gelen; sosyal, mekansal ve ekonomik yaklaşımları keskin biçimde farklılaşan iki projenin karşılaştırmalı değerlendirmesi üzerinden eleştirel bir bakış getirmeyi amaçlamaktadır. Illk proje, Avrupa Birliği ve Fatih Belediyesi öncülüğünde 2003 ve 2008 yılları arasında uygulaması gerçekleşen Fener Balat Rehabilitasyon Projesi, ikincisi ise hazırlık süreci 2007 yılında başlayan ve Fatih Belediyesi'nin özel bir firmaya ihale yoluyla başlattığ 1 Fener Balat Ayvansaray Kentsel Yenileme Projesi'dir. 
EVREN AYSEV DENEÇ; B. Arch., M. Arch., PhD.

Received her B.Arch. from Middle East Technical University Faculty of Architecture (1996). Received her M. Arch. from Columbia University Advanced Architectural Design Program, N.Y (1998). Earned her PhD. in Architecture from İstanbul Technical University Faculty of Architecture (2013). Currently is the founding partner of Açıkofis Architects. Major research interests include architectural design, urban space production and Istanbul. eaysev@gmail.com 